\title{
Lowering Emission using Single Venturi Vacuum in the Wet Scrubber System
}

\author{
Shofiana Istiqomah, Rachmat Boedisantoso, Abdu F. Assomadi, Arie D. Syafei, Ary B.K Putra
}

\begin{abstract}
Burning plastic waste using an incinerator will produce emissions of gas that will damage the environment if released casually. This research was conducted to analyze the effect of air flow, water discharge and thickness of the packing media on the efficiency of the wet scrubber in removing emissions from the combustion of plastic waste. There are 3 variable variations, air flow velocity, water flow velocity, and thickness of media with thickness of $5 \mathrm{~cm}, 10 \mathrm{~cm}$ and $15 \mathrm{~cm}$. The parameters to be investigated are the $\mathrm{SO}_{2}, \mathrm{NO}$ and $\mathrm{CO}$ content and temperature at the wet scrubber. The results obtained from the experiments carried out were $\mathrm{SO}_{2}$ efficiency values of $46.80 \%, \mathrm{CO}$ of $26.70 \%$ and $\mathrm{NO}$ of $23.68 \%$. $\mathrm{SO}_{2}$ values tend to have high efficiency values because $\mathrm{SO}_{2}$ solubility in water is high. In accordance with the effect test with the help of IBM SPSS, water flow and venturi flow greatly influence the removal of $\mathrm{NO}, \mathrm{CO}$ and $\mathrm{SO}_{2}$ gases. However, the thickness of the media only affects the removal of $\mathrm{CO}$ and $\mathrm{SO}_{2}$ gases.
\end{abstract}

Keywords: Venturi vacuum, air flow velocity, water discharge and media thickness.

\section{INTRODUCTION}

The problem of waste in Indonesia is something that has not been resolved to date. Increasing the number of residents will result in increased waste generated. One of the problems of rubbish is plastic waste which has the potential to pollute the environment if there is no control over usage. As many as 300 million ton of plastics waste are produced annually and around 50\% is thrown away [1]. In Surabaya, the amount of waste generated reached 2,160 tons / day with plastic waste of 10.09 tons / day [2]. Data from the Ministry of Industry, imports of polypropylene (PP) products continue to increase along with the growth in consumption of chemicals. In the data mentioned. In 2012, polypropylene (PP) consumption was 1.3 million tons per year and increased in 2013 to 1.46 million tons. In general, solid waste contains $12 \%$ plastic waste which, if carried out by burning, releases toxic gases such as dioxin, furan, mercury into the atmosphere [3]. In addition to small particles, $\mathrm{NO}, \mathrm{SO}_{2}$ and $\mathrm{CO}$ are emissions from combustion gases [4].

Revised Manuscript Received on January 14, 2020.

* Correspondence Author

Shofiana Istiqomah, Environmental Engineering, Sepuluh Nopember Institute of Technology, Surabaya, Indonesia. Email: shofianaistiqomah@ gmail.com

Rachmat Boedisantoso, Environmental Engineering, Sepuluh Nopember Institute of Technology, Surabaya, Indonesia. Email: boedirb@yahoo.com

Abdu Fadli Assomadi, Environmental Engineering, Sepuluh Nopember Institute of

Technology, Surabaya, Indonesia. Email: abdufadliassomadi@ gmail.com

Arie D. Syafei, Environmental Engineering, Sepuluh Nopember Institute of Technology, Surabaya, Indonesia. Email: abdufadliassomadi@gmail.com

Ary B.K Putra, Environmental Engineering, Sepuluh Nopember Institute of Technology, Surabaya, Indonesia. Email: abdufadliassomadi@gmail.com
One effort that can be done to reduce amount of plastic waste is to do plastic waste incineration. We often encounter in the area around that one of them is burning plastic in the open. In fact, combustion with a system like this is the main source of air pollution. To prevent air pollution caused by incineration activities, we need a tool that is able to control the emission output from the combustion process carried out. The gas control device used in this study is a scrubber with a type of wet scrubber that is placed at the end of the combustion process before air is released into the environment. Wet Scrubber has been proven to be able to reduce SOx emissions up to $90 \%$ so that it is appropriate to control the emission of incinerator exhaust gases [5].

According to the Environmental Protection Agency (EPA), the term wet scrubber is a device that is useful for removing flue gas pollutants from furnaces or from other gas streams. This device is used to clean air, exhaust gases or other gases from various pollutants and dust particles by making contact between pollutants and scrubbing solutions.

\section{MATERIAL AND METHODS}

\section{A. Research Preparation}

The tool that will be used in this research is the Wet Scrubber type Co Current with a single venturi vacuum. Gas coming out of the Heat Exchanger will flow and some will go into the venturi pipe due to a pressure difference. Furthermore, the air that is combined with water will enter the wet scrubber to be cleaned with absorbent in the form of PDAM water which will later be collected in a reservoir. The wet scrubber design can be seen in Figure 1.

\section{B. Wet Scrubber Process}

In the incineration process, the waste is put into the primary burner chamber where the plastic waste will be combusted with a preheated charcoal lighter. At the pre burner stage, $30 \%$ of the mass will remain in the furnace in the form of non-burnt material and sediment ash. Combustion gases will enter through the primary chamber to be burned again and then into the secondary chamber. With this two-burn process the carbonization gases produced from the first combustion chamber will be burned up in the second combustion chamber. Gas that has been burned in the second combustion chamber will be lowered by passing the heat exchanger. The temperature reduction is done so that later the gas that enters the wet scrubber in a cold state so that no gas explosion occurs due to the contact of hot gas with the air absorber. 


\section{Lowering Emission using Single Venturi Vacuum in the Wet Scrubber System}

The gas that has been cooled will pass through the main gas pipe to get to the wet scrubber and some others will be drawn through the venturi vacuum to be mixed with the water absorber before entering the wet scrubber. The attraction of the gas to the venturi vacuum is due to the application of the Bernoulli principle applied to the venturi vacuum. When the gas fluid passes through the pipe with a small cross section, the fluid rate will increase. Based on
Bernoulli's principle, the fluid pressure in the narrow pipe component is smaller if the fluid flow rate is greater. This is known as the venturi effect, which shows quantitatively that the fluid flow rate is high, so the fluid pressure becomes small. Venturi neck pressure is low from environmental pressure is the key technology where gas can enter the venturi through micro holes that have been fabricated in the venturi neck.

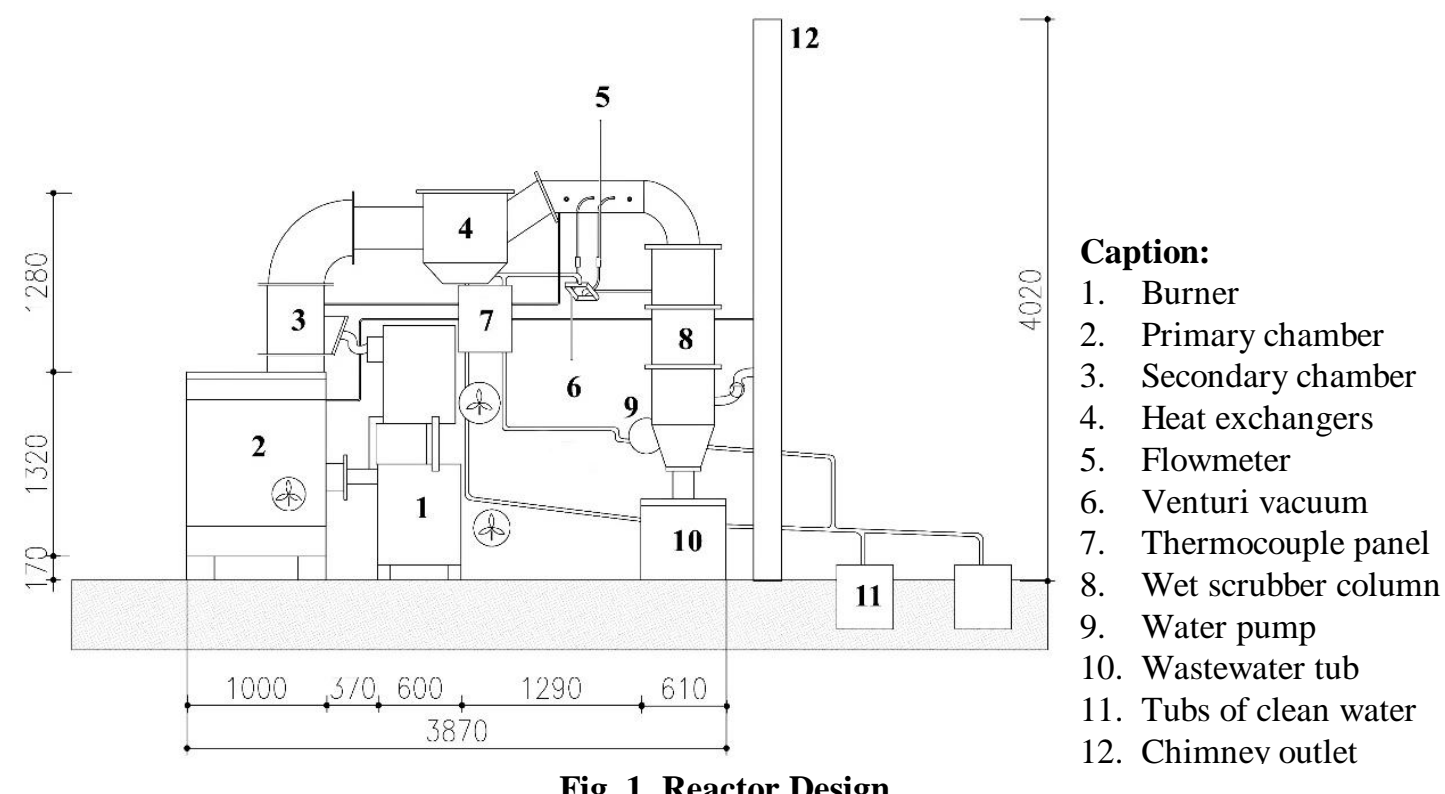

\section{Research Implementation}

The study based on three variables. The first variation is the amount of water discharge that is 15, 20 and $25 \mathrm{l} / \mathrm{min}$. The second variation is the gas flow rate at venturi vacuum of 12 , 14 and $16 \mathrm{l} / \mathrm{min}$. The third variation is the thickness of the media is $5 \mathrm{~cm}, 10 \mathrm{~cm}$, and $15 \mathrm{~cm}$. The research procedure is as follows:

1. Prepare Polypropylene-plastic $1 \mathrm{~kg}$ as incinerator fuel

2. Insert Polypropylene-plastic as the material into the primary chamber

3. Arranging the reactor with the variation of research needed (the number of venturi, the filter media size, and the height of the filter media)

4. Turn on the burner as a trigger for fire in the primary chamber

5. Turn on the blower as an air supplier to keep the fire burning during combustion

6. Turn on the water pump to distribute water into the reactor

7. Combustion emissions from the incinerator flow to the heat exchanger through the reactor pipe

8. Adjust the rate of air flow into the wet scrubber by adjusting the gas discharge value on the flowmeter

9. Monitor the temperature values on the thermocouple and make sure the combustion has reached the maximum temperature

10. Turn on the stopwatch and take measurements.

11. Monitor and record the value of gas emissions at the wet scrubber inlet and outlet every minute on the gas analyzer within 10 minutes by burning $1 \mathrm{~kg}$ of Polypropylene-plastic

\section{Efficiency of Using Venturi Vacuum}

The study was conducted to determine the efficiency of the wet scrubber by adding venturi pipes in setting aside combustion gas emissions. Emission values are taken from the inlet gas and wet scrubber outlet gas for $1 \mathrm{~kg}$ burning PP type plastic bags lasts (10 minutes). Emission value data obtained will be analyzed and discussed so that it will get the highest efficiency value from each variation made. The study was conducted in 27 experiments with 3 variables and 3 variations on each variable. Done with the same treatment adjusted for the variations applied.

The resulting incinerator emission gas removal efficiency value can show the performance of the one stage wet scrubber reactor. The greater the resulting efficiency values indicate that the performance of the three-stage scrubber reactor is getting better. Efficiency values are calculated by Equation 1.

$$
\begin{aligned}
& \quad \eta=(\text { c in }- \text { c out }) / c \text { in } x 100 \% \\
& \eta \quad=\text { gas emission removal efficiency }(\%) \\
& \text { Cin } \quad=\text { concentration of inlet gas }(\mathrm{ppm}) \\
& \text { Cout }=\text { concentration of outlet gas }(\mathrm{ppm})
\end{aligned}
$$

\section{RESULT AND DISCUSSION}

The results are obtained from the calculation of efficiency and the relationship between variables using Anova spss statistics. For efficiency 
values obtained from previous calculations and statistical results obtained by entering efficiency values into statistics.

\section{A. Result of Efficiency}

The result of efficiency wet scrubber using single venturi vacuum can be seen in table I. From tables I and II it can be seen that each variation produces different efficiency values. The highest allowance for emissions is found in $\mathrm{SO}_{2}$ gas removal where almost $50 \%$ can be reduced before being discharged into the environment. This is consistent with the study of Kaye and Laby in 1986 which stated that $\mathrm{SO}_{2}$ has higher water solubility than $\mathrm{NO}$ and $\mathrm{CO}$ gases [7]. $\mathrm{SO}_{2}$ solubility in water is $11.28 \mathrm{gr} / 100 \mathrm{gr}$ water, NO $10.19 \mathrm{gr} / 100$ gr water, and CO $0.0028 \mathrm{gr} / 100 \mathrm{gr}$ water.

Table I. Efficiency of NO, CO, and $\mathrm{SO}_{2}$

\begin{tabular}{|c|c|c|c|c|c|}
\hline $\begin{array}{c}\text { Water } \\
\text { Discharge } \\
(1 / \mathrm{min})\end{array}$ & $\begin{array}{c}\text { Media } \\
\text { Thickness } \\
(\mathrm{cm})\end{array}$ & $\begin{array}{c}\text { Gas Flow } \\
(1 / \mathrm{min})\end{array}$ & NO & $\mathrm{CO}$ & $\mathrm{SO}_{2}$ \\
\hline \multirow{9}{*}{15} & \multirow{3}{*}{5} & 12 & 19.16 & 11.62 & 13.19 \\
\hline & & 14 & 16.24 & 45.41 & 32.79 \\
\hline & & 16 & 25.47 & 20.61 & 63.54 \\
\hline & \multirow{3}{*}{10} & 12 & 18.55 & 28.18 & 14.37 \\
\hline & & 14 & 41.38 & 35.81 & 38.06 \\
\hline & & 16 & 23.84 & 39.93 & 75.02 \\
\hline & \multirow{3}{*}{15} & 12 & 21.98 & 21.72 & 34.94 \\
\hline & & 14 & 26.73 & 10.42 & 48.05 \\
\hline & & 16 & 22.34 & 22.04 & 53.22 \\
\hline \multirow{9}{*}{20} & \multirow{3}{*}{5} & 12 & 13.5 & 6.38 & 65.34 \\
\hline & & 14 & 18.91 & 10.24 & 48.32 \\
\hline & & 16 & 21.09 & 8.17 & 30.36 \\
\hline & \multirow{3}{*}{10} & 12 & 41.84 & 38.36 & 41.92 \\
\hline & & 14 & 31.55 & 29.86 & 49.05 \\
\hline & & 16 & 21.99 & 16.2 & 35.78 \\
\hline & \multirow{3}{*}{15} & 12 & 29.53 & 26.13 & 30.48 \\
\hline & & 14 & 27.91 & 22.24 & 56.63 \\
\hline & & 16 & 36.1 & 35.26 & 57.44 \\
\hline \multirow{9}{*}{25} & \multirow{3}{*}{5} & 12 & 10.44 & 19.11 & 72.29 \\
\hline & & 14 & 11.43 & 42.58 & 92.91 \\
\hline & & 16 & 27.74 & 28.19 & 78.74 \\
\hline & \multirow{3}{*}{10} & 12 & 20.69 & 18.27 & 26.72 \\
\hline & & 14 & 42.86 & 54.26 & 35.74 \\
\hline & & 16 & 29.03 & 39.21 & 48.45 \\
\hline & \multirow{3}{*}{15} & 12 & 4.23 & 18.72 & 31.06 \\
\hline & & 14 & 10.05 & 38.64 & 41.15 \\
\hline & & 16 & 24.81 & 33.46 & 47.98 \\
\hline
\end{tabular}

\section{B. Result of One Way Anova}

The result of one-way anova statistic test can be seen in table II.

Table II. One Way Anova Statistic Test Result

\begin{tabular}{|c|c|c|c|}
\hline Variables & $\mathrm{NO}$ & $\mathrm{CO}$ & $\mathrm{SO}_{2}$ \\
\hline Water Discharge & 0.348 & 0.176 & 0.471 \\
\hline Gas Flow & 0.024 & 0.119 & 0.251 \\
\hline
\end{tabular}

Media Thickness

0.393

0.168

0.128

From the Anova test results, it can be seen that gas flow and media thickness test on the efficiency of $\mathrm{SO}_{2}$ and $\mathrm{CO}$ gas has a significance value of more than 0.1 . So it can be concluded that the initial hypothesis that there is a relationship between variables and efficiency is acceptable. As for the variable gas flow to NO gas efficiency has a significance value of 0.024 which means that there is no relationship between the variable gas flow with NO gas efficiency.

\section{CONCLUSION}

There is an influence between water discharge, gas flow and media thickness on the efficiency of $\mathrm{SO}_{2}$ and $\mathrm{CO}$ gas removal. Whereas the variables that affect the allowance for gas emissions are only the water discharge and media thickness variables.

\section{ACKNOWLEDGMENT}

Authors express gratitude to all lecturer of Department of Environmental Engineering, Faculty of Civil, Environment, and Geo-Engineering, Sepuluh Nopember Institute of Technology for every suggestion and viewpoint, as well to all of the government agency that gives permission and allows us to do this research. The authors also would like to thank LPPM ITS through the scheme of Penelitian Unggulan Perguruan Tinggi 2019 for funding this research.

\section{REFERENCES}

1. Shingh, P., Sharma, VP. 2016. Integrated Plastic Waste Management Environmental and Improved Health Approaches. Procedia Environmental Sciences 35 ( 2016 ) $692-700$.

2. Trihadiningrum, Y. 2006. Reduction potential of domestic solid waste in Surabaya City, Indonesia. Proceedings, The $4^{\text {th }}$ International Symposium on Sustainable Sanitation, Bandung, 4-6 September 2006. ISBN 979-26-2496-1

3. Verma, R., Vinoda, K., Papireddy, M., Gowda, N. 2015. Toxic Pollutants from Plastic Waste- A Review. International Conference on Solid Waste Management, 5IconSWM 2015.

4. Franchini, M., Rial, M., Buiatti, E., Bianchi, F. (2004). Health effects of exposure to waste incinerator emissions: a review of epidemiological studies. Istituto di Fisiologia Clinica 40(1):101-115.

5. Quina, M.J., Bordado, J.C.M., Quinta Ferreira, R.M. 2008. Air Pollution Control in Municipal Solid Waste Incinerators. Instituto Superior Técnic, Portugal

\section{AUTHOR PROFILE}

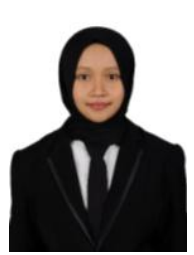

Shofiana Istiqomah, is usually called Shofi, born in Blitar on October 20, 1994. The author studied elementary school in 2001-2004 in MI Assyafi'iyah Pikatan and in 2004-2007 in MI Perwanida Blitar. Then, the author continued his education at MTs until Aliyah in 2007-2013 at MTs and MA Al-Mawaddah (Pesantren Putri Al-Mawaddah) Coper, Ponorogo. After completing Aliyah's education, the writer continued his Higher Education at Surabaya State Polytechnic majoring in D4 Occupational Safety and Health Engineering in 2013-2017. Then, the writer continued his higher education at the Masters in Environmental Engineering Sepuluh November Institute of Technology in 2018. The author has done Practical Work at PT. Freeport Indonesia and the National Nuclear Energy Agency in Yogyakarta in 2016. All forms of communication to be conveyed to the author can be delivered via

shofianaistiqomah@gmail.com email

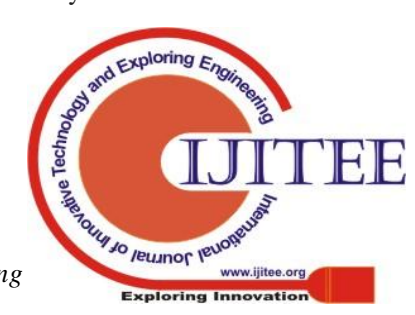

